\title{
Detection of Xanthomonas axonopodis pv. vignicola, causal agent of bacterial blight of cowpea in seeds by non-serological methods
}

\author{
R. NANDINI AND SHRIPAD KULKARNI* \\ Department of Plant Pathology, University of Agricultural Sciences, DHARWAD (KARNATAKA) INDIA
}

\section{ARITCLE INFO}

Received : 15.03 .2014

Revised : 20.07 .2014

Accepted : 05.08.2014

\section{KEY WORDS :}

Cowpea, Bacterial blight, Xanthomonas axonopodis pv. vignicola
*Corresponding author:

Email: shripadkulkarni@ rocketmail.com

\begin{abstract}
Among the diseases infecting cowpea, bacterial blight caused by Xanthomonas axonopodis pv. vignicola (Burkholder,1944). Vauterin et al. (1995) is a major production constraint. First necrotic lesions are formed on leaves and later the stem is attacked and the pathogen reaches vascular bundles and the disease becomes systemic. In the present study, attempted have been made to develop the suitable methods for the detection of the pathogen in the seeds and to find out the nature of transmission using selective and semi-selective media and compare them for their efficacy. Results indicated NSCAA medium to be more efficient in recovering the colonies of seed borne bacterium Xanthomonas axonopodis pv. vignicola with $132 \times 10^{5}$ $\mathrm{cfu} / \mathrm{ml}$ as compared to $75 \times 10^{5} \mathrm{cfu} / \mathrm{ml}$ of colonies on Nutrient agar. The next best medium was SIBU agar $\left(126 \times 10^{5} \mathrm{cfu} / \mathrm{ml}\right)$ followed by XTS medium $\left(118 \times 10^{5} \mathrm{cfu} / \mathrm{ml}\right)$. All the media for isolation of plant pathogenic bacterium from seeds revealed that the cowpea bacterium is seed borne in nature. Another method employed to detect pathogen in seeds is Van Vuurde et al.(1983) method and results revealed that unsterilized seeds of susceptible cultivar C-152 yielded more number of colonies $35 \times 10^{2} \mathrm{cfu} / \mathrm{ml}$ by direct plating the seed extract on NSCAA whereas the resistant germplasm, DCS $47-1$ yielded very less number of colonies $2 \times 10^{2}$ from diseased unsterilized seeds confirming its seed borne nature.
\end{abstract}

How to view point the article : Kulkarni, Shripad and Nandani, R. (2014). Detection of Xanthomonas axonopodis pv. vignicola, causal agent of bacterial blight of cowpea in seeds by non-serological methods. Internat. J. Plant Protec., 7(2) : 292-297. 